Terbit online pada laman : http://teknosi.fti.unand.ac.id/

\title{
Perangkat Lunak untuk Kontrol dan Pendeteksian QR Code pada Robot Mobil di Prototipe Pabrik Garmen
}

\author{
Juan Steven ${ }^{a}$, Resmana Lim ${ }^{a, *}$ \\ "a Program Studi Teknik Elektro, Universitas Kristen Petra, Jl. Siwalankerto No. 121-131, Surabaya, 60236, Indonesia"
}

\section{INFORMASI ARTIKEL}

Sejarah Artikel:

Diterima Redaksi: 11 November 2021

Revisi Akhir: 18 Januari 2022

Diterbitkan Online: 21 Januari 2022

\section{QR Code,}

Material Handling,

Autonomous Mobile Robot,

Navigasi

\section{KORESPONDENSI}

E-mail: resmana@petra.ac.id *

\section{A B S T T R A C T}

FTI UK Petra akan membangun pabrik garmen mini yang membutuhkan robot otonom. Robot otonom ini akan melakukan tugas material handling dalam pabrik tersebut. Oleh sebab itu, penelitian ini bertujuan untuk merancang perangkat lunak untuk mendukung tugas tersebut. Adapun robot otonom ini tergolong sebagai AMR (Autonomous Mobile Robot) karena dapat bergerak bebas pada lingkungan tanpa memerlukan bantuan garis atau tanda lainnya. Robot ini dilengkapi dengan sensor LIDAR untuk mendeteksi keadaan lingkungan sekitarnya secara 360 derajat. Dengan adanya sensor ini robot dapat melakukan pemetaan terhadap pabrik garmen dengan memanfaatkan metode SLAM. Robot juga dapat melakukan navigasi secara otonom dengan memanfaatkan pembacaan Sensor LIDAR dan algoritma DWA. Dari penelitian yang telah dilakukan, penulis menemukan bahwa perangkat lunak yang telah didesain mampu melakukan navigasi otonom dengan waktu yang kurang lebih sama dengan navigasi secara teleoperasi dan robot mampu mendeteksi QR Code pada jarak 10-20 cm menggunakan kamera. Dengan demikian, penelitian ini telah berhasil menghasilkan perangkat lunak untuk robot otonom yang akan digunakan pada pabrik garmen mini.

\section{PENDAHULUAN}

Dalam beberapa tahun terakhir perkembangan teknologi diera digital semakin pesat. Perkembangan tersebut harus sejalan dengan kemajuan sumber daya manusianya. Untuk menghadapi hal itu Universitas Kristen Petra terus berupaya dalam meningkatkan kualitas belajar mahasiswa. Salah satu upaya tersebut merupakan rencana dari Fakultas Teknologi Industri (FTI) untuk membangun fasilitas yang berteknologi tinggi. Hal ini diharapkan dapat mendukung kegiatan belajar mahasiswa di dalam kampus. Rencana tersebut merupakan pembangunan pabrik garmen mini yang cerdas. Terdapat beberapa teknologi canggih yang dapat mendukung kegiatan belajar di dalam fasilitas tersebut. Salah satu teknologinya adalah penerapan Autonomous Mobile Robot atau disingkat AMR untuk melakukan sebuah tugas. AMR merupakan sebuah perangkat mekanis yang dapat diprogram untuk dapat bergerak bebas di lingkungan yang terdapat rintangan, menjalankan berbagai jenis fungsi, dan memperoleh informasi lingkungan melalui sensor [1]-[4].

Berdasarkan wawancara dengan koordinator dari pabrik garmen di FTI, AMR yang dibutuhkan akan berfungsi untuk melakukan tugas material handling di area pabrik. Material handling merupakan tugas yang menangani perpindahan, perlindungan, penyimpanan, dan pengendalian bahan dan produk di seluruh area manufaktur [5]-[8]. Untuk itu robot ini harus bisa mengenali area pabrik agar dapat menuju ke tujuan yang diharapkan. Serta robot juga harus mengenali titik-titik koordinat lokasi yang menjadi tujuan dalam setiap perjalanannnya. Untuk mengenali titik-titik koordinat tujuan digunakan pendeteksian label QR Code oleh robot. Hal ini bertujuan agar robot dapat mengenali nama stasiun dengan mudah. QR Code merupakan kode yang terdiri dari modul hitam yang disusun dalam pola kotak pada latar belakang putih. Kode ini merupakan jenis kode batang matriks atau kode dua dimensi yang dapat menyimpan informasi data. Informasi yang dikodekan bisa berupa teks, URL, atau data lainnya. QR sendiri 
merupakan singkatan dari "Quick Response" yang menunjukkan bahwa isi kode harus bisa dibaca dengan sangat cepat [9]-[13].

Setelah mendeteksi QR Code robot juga harus bisa melakukan navigasi secara otonom untuk menentukan jalannya sendiri menuju stasiun tujuan. Navigasi pada robot merupakan algoritma perencanaan yang menghasilkan jalur yang terdiri dari jalur lurus dan tikungan menuju ke tujuan [14]. Agar robot dapat berfungsi sebagaimana fungsinya dibutuhkan perangkat lunak pada robot tersebut yang dapat melakukan pemetaan, pendeteksian QR Code, dan navigasi secara otonom. Maka dari itu penelitian ini dilakukan untuk memenuhi kebutuhan perangkat lunak tersebut.

Terdapat penelitian sebelumnya oleh Zhang mengenai robot mobil yang melakukan lokalisasi dan pemetaan menggunakan QR Code pada lingkungan dalam ruangan [15]. Pada penelitian ini Zhang menggunakan Laser Range Finder (LRF) untuk membangun peta lingkungan dan navigasi. Kemudian digunakan Industrial Camera yang menghadap ke plafon untuk mendeteksi QR Code yang direkatkan pada plafon. Pose dari robot dapat diketahui dengan mengestimasikan posisi dari QR Code dan robot itu sendiri. QR Code direkatkan pada plafon setiap $140 \mathrm{~cm}$, sehingga semakin besar area maka semakin banyak QR Code yang digunakan. Perangkat lunak yang dibuat oleh penulis merupakan perkembangan dari penelitian yang dilakukan oleh Zhang. Pada penelitian ini hanya menggunakan QR Code pada titik lokasi tujuan saja.

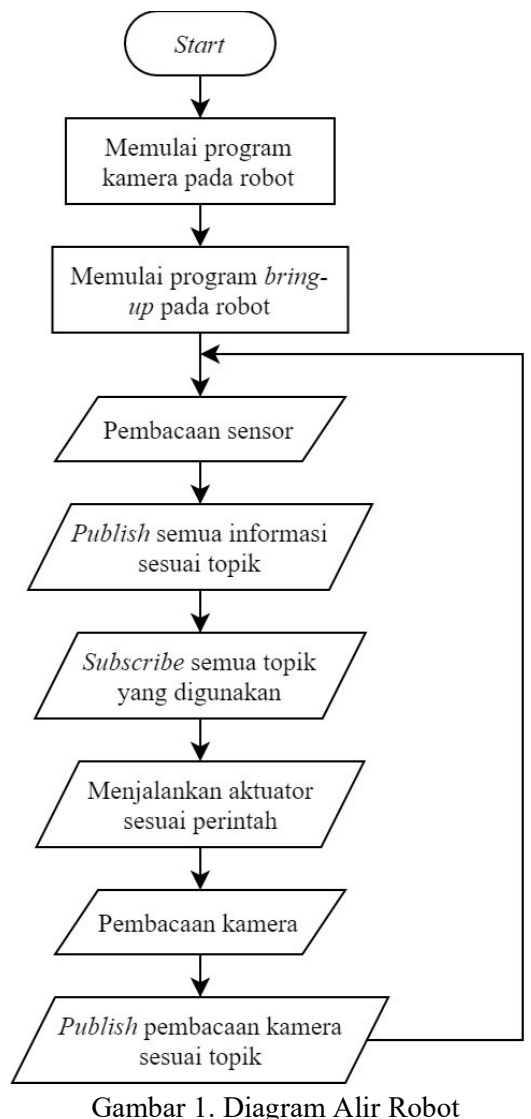

Gambar 1. Diagram Alir Robot

\section{METODE}

\subsection{Membuat Program}

Pada gambar 1, mula-mula sistem menjalankan program untuk membaca gambar dari kamera. Kemudian sistem menjalankan program bring-up yaitu program yang membaca lingkungan dengan sensor dan publish data pembacaan tersebut. Program bring-up juga subscribe topik-topik tertentu untuk menjalankan aktuator. Kemudian sistem publish juga hasil pembacaan gambar dari kamera. Sistem ini akan berulang terus-menerus agar robot dapat berfungsi sesuai yang diharapkan.

Dalam penelitian ini penulis menggunakan bahasa program populer yang bernama Python. Terdapat 5 program yang dibuat yaitu:

1. Program QR Code, ini merupakan program yang membaca gambar dari pembacaan kamera kemudian mendeteksi QR Code dan publish hasil pembacaan tersebut ke topik "qrcode".

2. Program utama, ini merupakan program yang mengontrol seluruh jalannya sistem.

3. Program automatic, ini merupakan program yang menjalankan robot menuju ke titik tujuan sesuai urutan tujuan secara terus menerus.

4. Program manual, ini merupakan program yang menjalankan robot menuju ke titik tujuan sesuai urutan tujuan hanya satu kali saja.

5. Program docking, ini merupakan program yang menjalankan robot untuk kembali ke titik "Home" atau ke titik "Docking" sesuai perintah.

Program-program diatas terhubung satu dengan yang lainnya dan melakukan komunikasi berdasarkan topik masing-masing. Berikut merupakan grafik diagram dari hubungan tiap node dan topik.

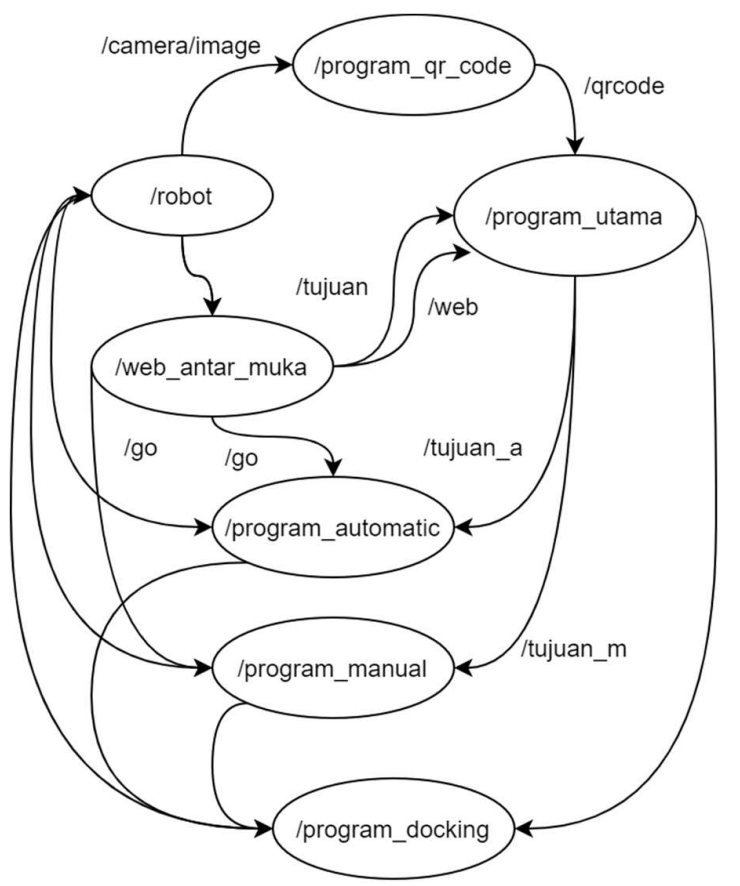

Gambar 2. Diagram Hubungan Node dan Topik 
Pada gambar 2, dapat dilihat bahwa tiap program memiliki fungsinya masing-masing yang dapat menerima dan mengirimkan informasi melalui sistem subscribe dan publish yang disediakan oleh ROS.

\subsubsection{Program QR Code}

Program QR Code ini akan berjalan sesuai dengan diagram alir di bawah ini.

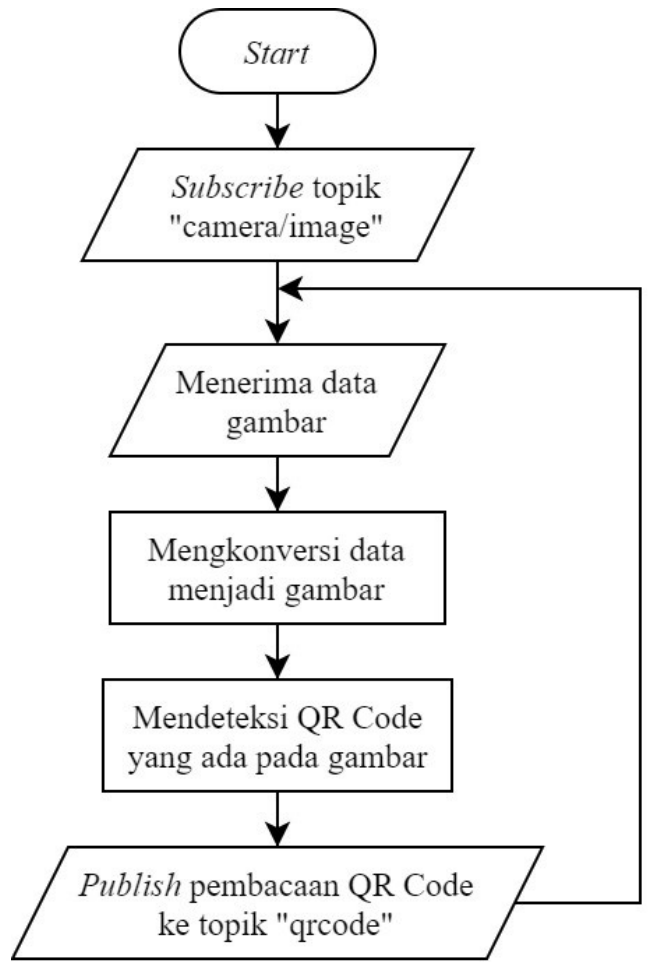

Gambar 3. Diagram Alir Program QR Code

Pada program QR Code seperti pada gambar 3, mula-mula sistem subscribe pada topik "camera/image" untuk menerima data gambar yang di-publish oleh robot. Kemudian data gambar tersebut dikonversi menjadi gambar agar dapat mendeteksi QR Code. Setelah dikonversi menjadi gambar, sistem mulai mendeteksi atau membaca QR Code yang ada pada gambar. Ketika QR Code sudah terdeteksi dan membaca sebuah teks. Teks tersebut di-publish ke topik "qrcode" agar dapat digunakan oleh program lain.

\subsubsection{Program Utama}

Pada program utama seperti pada gambar 4 sistem subscribe ke topik "web", "tujuan", dan "qrcode". Kemudian pada topik "web" sistem menerima pesan yang merupakan perintah atau input dari website pengguna. Jika pesan dari topik "web" tersebut merupakan "Start-Mapping" maka sistem akan menjalankan RVIZ SLAM Gmapping. Jika pesan dari topik "web" merupakan
"Save-Map" maka sistem akan menyimpan peta yang telah dibuat dengan nama "map" dan format gambar "pgm". Setelah itu sistem akan memberhentikan RVIZ SLAM Gmapping. Jika pesan dari topik "web" merupakan "Start-Register" maka sistem akan menjalankan RVIZ Navigation. Jika pesan dari topik "web" merupakan "Stop-Register" maka sistem akan memberhentikan RVIZ Navigation. Jika pesan dari topik "web" merupakan "StartTask" maka sistem akan menjalankan RVIZ Navigation. Kemudian sistem membaca titik koordinat "Home" dan publish titik koordinat tersebut pada topik "initialpose" agar sistem mengetahui lokasi robot berada di "Home". Jika pesan dari topik "web" merupakan "Stop-Robot" maka sistem akan menjalankan program yang bernama "docking". Jika pesan dari topik "web" merupakan "Stop-Task" maka sistem akan menjalankan program "docking". Setelah program "docking" selesai sistem akan memberhentikan RVIZ Navigation.

Ketika sistem menerima pesan pada topik "tujuan" maka sistem akan memeriksa isi pesan tersebut. Jika isi pesan tersebut merupakan "Automatic" maka sistem akan menjalankan program yang bernama "automatic". Jika isi pesan tersebut merupakan "Manual" maka sistem akan menjalankan program yang bernama "manual". Ketika sistem menerima pesan pada topik "qrcode" maka sistem akan membaca titik koordinat robot dari algoritma AMCL kemudian menyimpan titik koordinat tersebut dengan nama sesuai pembacaan QR Code. Sistem pada program utama ini akan berulang terus-menerus atau looping.

\subsubsection{Program Automatic}

Pada program automatic seperti pada gambar 5, mula-mula sistem memeriksa apakah robot berada di docking atau tidak. Jika robot berada di docking maka robot akan bergerak maju sejauh $60 \mathrm{~cm}$. Jika robot tidak berada di docking maka sistem akan membaca urutan dari stasiun tujuan yang akan dikunjungi oleh robot. Kemudian sistem membaca titik koordinat stasiun tujuan pertama dan publish titik koordinat stasiun tersebut agar robot dapat melakukan navigasi ke stasiun tujuan. Jika robot sudah sampai di stasiun tujuan pertama sistem menunggu perintah "Go" dari pengguna untuk melanjutkan ke stasiun tujuan kedua. Jika sistem sudah menerima perintah "Go" maka sistem membaca titik koordinat stasiun tujuan kedua dan publish titik koordinat stasiun tersebut. Kemudian robot melakukan navigasi ke stasiun tujuan kedua. Jika robot sudah sampai di stasiun tujuan kedua, sistem kembali menunggu perintah "Go" dari pengguna. Kemudian sistem lanjut membaca titik koordinat stasiun tujuan ketiga setelah menerima perintah "Go". Sistem publish titik koordinat stasiun tujuan ketiga dan robot segera melakukan navigasi ke stasiun tujuan ketiga. Ketika robot sudah sampai di stasiun tujuan ketiga, sistem menunggu perintah "Go" lagi dari pengguna. Setelah mendapat perintah "Go" dari pengguna sistem kembali membaca titik koordinat stasiun tujuan pertama lagi. Sistem ini berulang terus-menerus atau looping. 


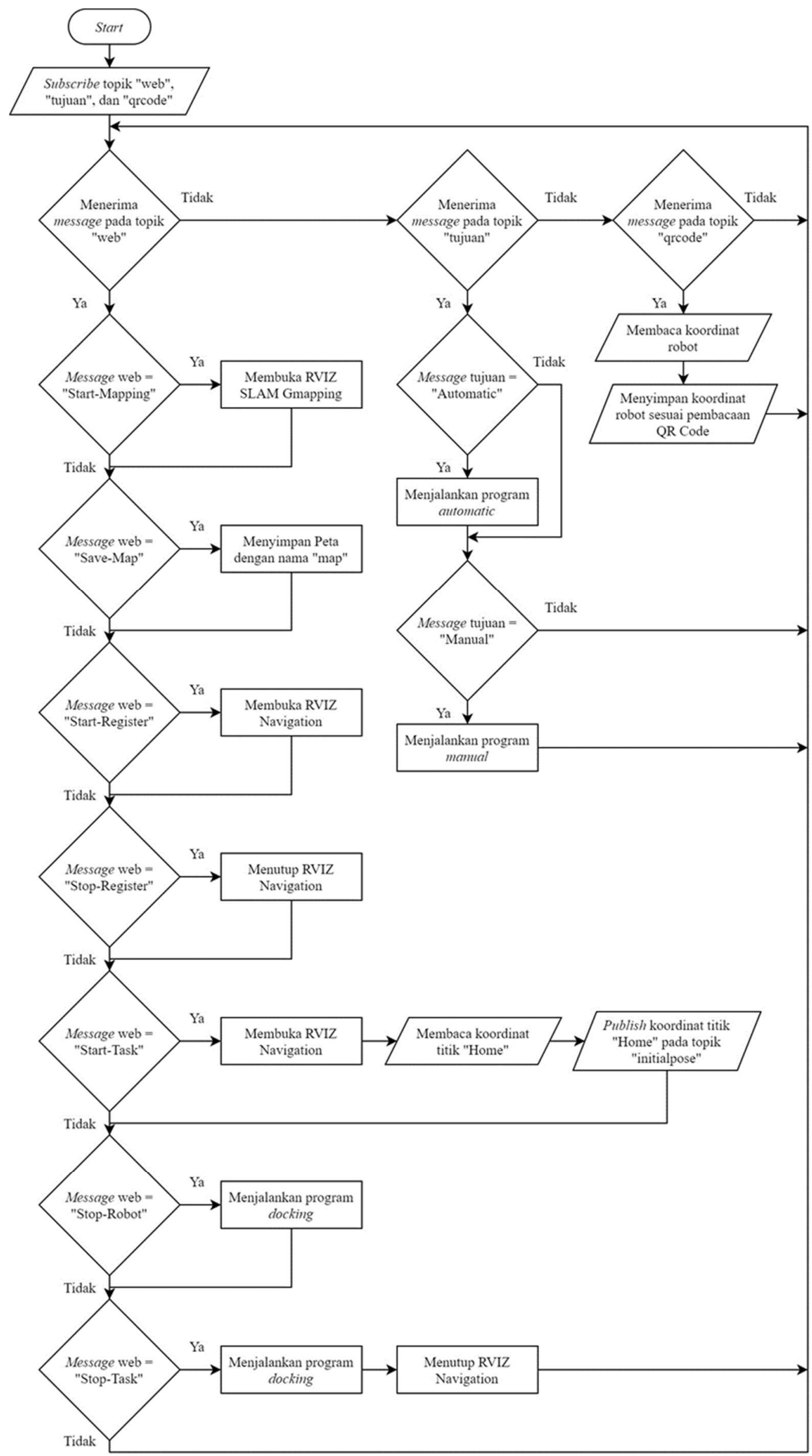

Gambar 4. Diagram Alir Program Utama 


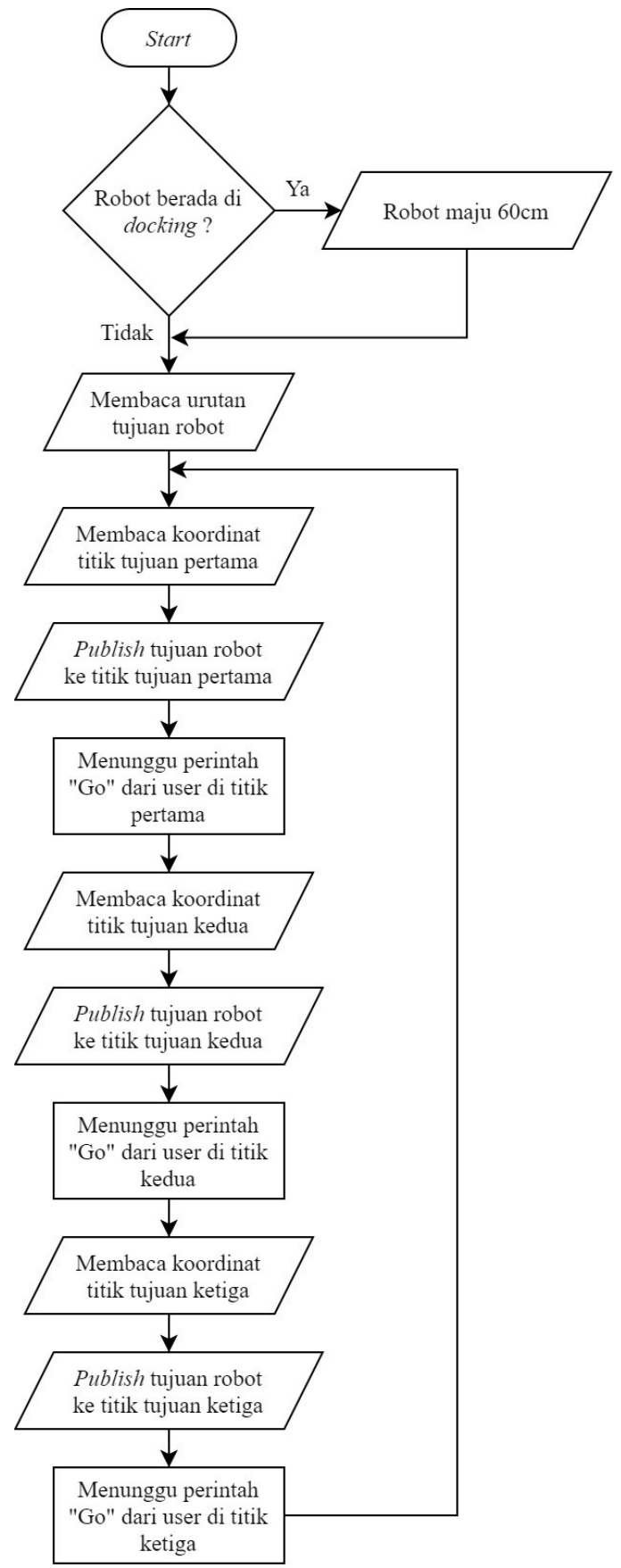

Gambar 5. Diagram Alir Program Automatic

\subsubsection{Program Manual}

Pada program manual seperti pada gambar 6, mula-mula sistem memeriksa apakah robot berada di docking atau tidak. Jika robot berada di docking maka robot akan bergerak maju sejauh $60 \mathrm{~cm}$. Jika robot tidak berada di docking maka sistem akan membaca urutan dari stasiun tujuan yang akan dikunjungi oleh robot. Kemudian sistem membaca titik koordinat stasiun tujuan pertama dan publish titik koordinat stasiun tersebut agar robot dapat melakukan navigasi ke stasiun tujuan. Jika robot sudah sampai di stasiun tujuan pertama sistem menunggu perintah "Go" dari pengguna untuk melanjutkan ke stasiun tujuan kedua. Jika sistem sudah menerima perintah "Go" maka sistem membaca titik

168 Juan Steven koordinat stasiun tujuan kedua dan publish titik koordinat tersebut. Kemudian robot melakukan navigasi ke stasiun tujuan kedua. Jika robot sudah sampai di stasiun tujuan kedua, sistem kembali menunggu perintah "Go" dari pengguna. Kemudian sistem menjalankan program docking setelah menerima perintah "Go" dari pengguna. Sampai pada proses ini program manual selesai.

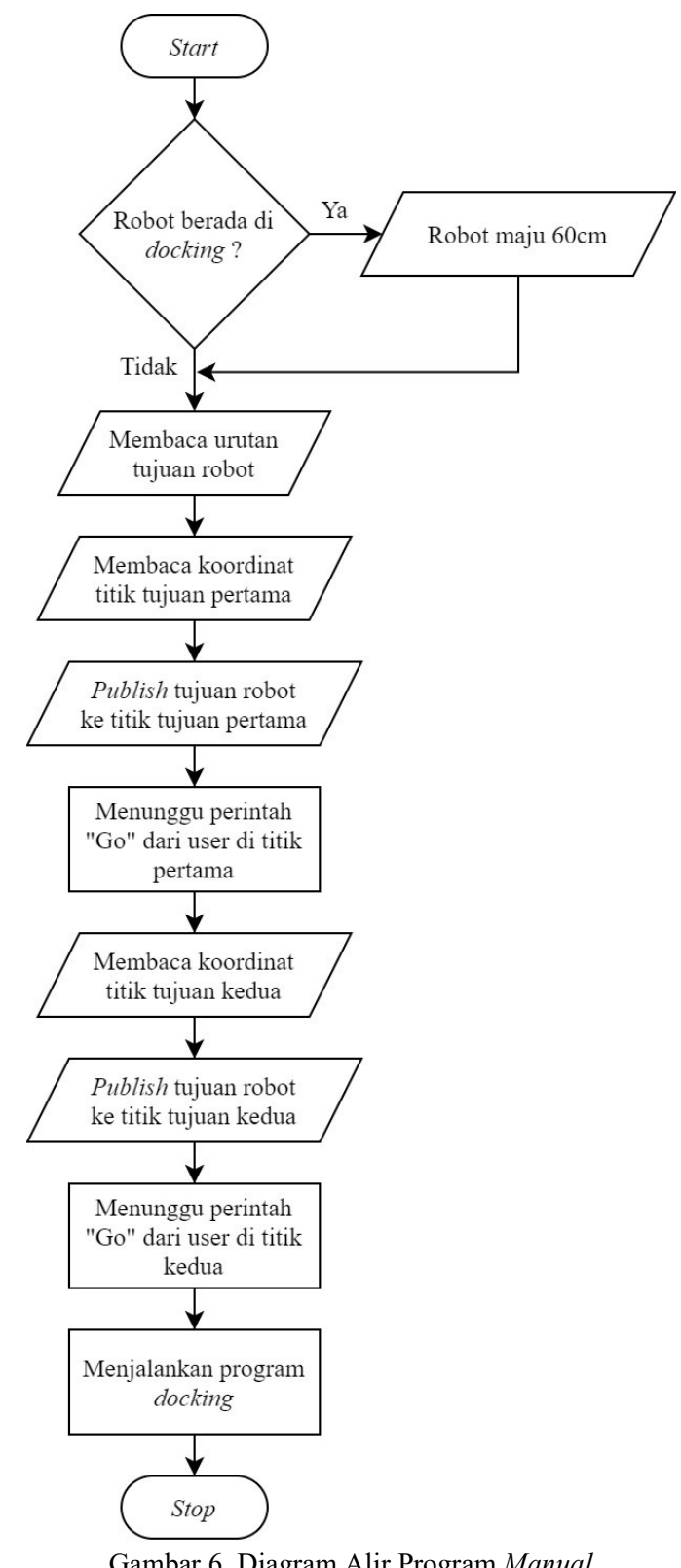

Gambar 6. Diagram Alir Program Manual

\subsubsection{Program Docking}

Pada program docking seperti pada gambar 7, mula-mula sistem memeriksa apakah robot berada di docking atau tidak. Jika robot berada di docking maka program docking akan selesai. Jika robot tidak berada di docking maka sistem akan membaca titik koordinat "Home" dan publish titik koordinat tersebut agar robot dapat melakukan navigasi ke "Home". Jika robot sudah sampai di "Home", robot melakukan line following sampai robot menyentuh docking.

https://doi.org/10.25077/TEKNOSI.v7i3.2021.164-171 


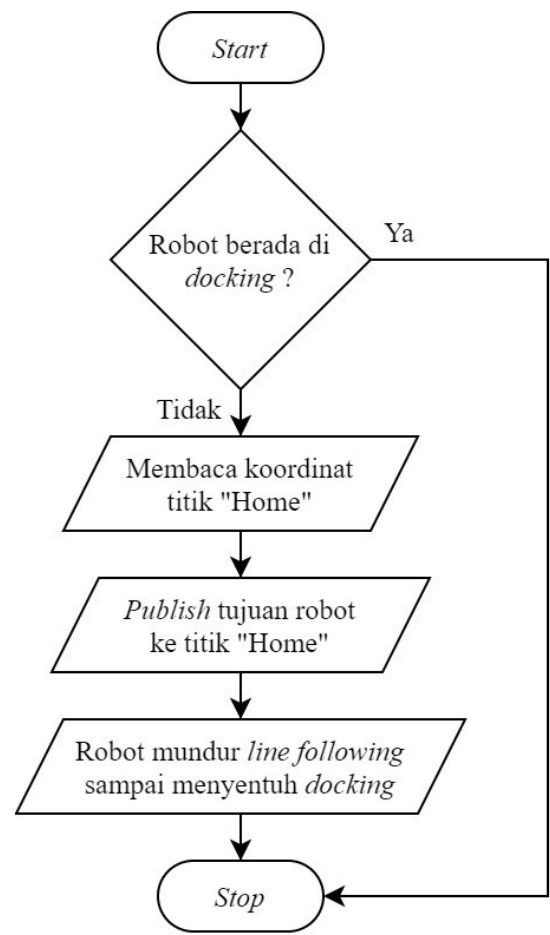

Gambar 7. Diagram Alir Program Docking

\subsection{Melakukan Pengujian}

Pengujian pada penelitian ini dilakukan di Laboratorium Elektronika milik Teknik Elektro Universitas Kristen Petra sebagai arena simulasi dari pabrik garmen yang akan dibangun.

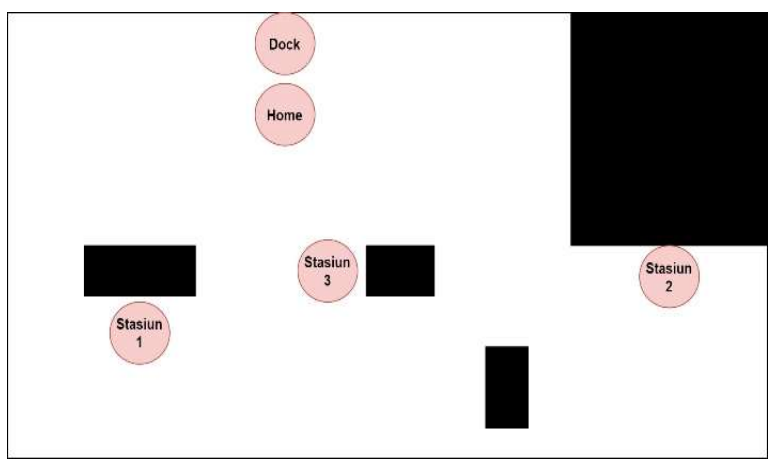

Gambar 8. Arena Simulasi Pengujian

Digunakan area seluas 33 meter persegi sebagai arena simulasi pada pengujian ini. Pada gambar 8 diatas, dapat dilihat terdapat beberapa rintangan berupa kotak yang mensimulasikan rak dan meja pada keadaan aslinya. Pada bagian kiri atas terdapat lokasi docking dan "Home". Kemudian terdapat tiga lokasi yang disimulasikan menjadi tiga stasiun.
Pada penelitian ini akan dilakukan dua tipe pengujian yaitu:

1. Pengujian pendeteksian QR Code. Pada pengujian ini diletakkan QR Code berukuran 5 x $5 \mathrm{~cm}$ disalah satu stasiun pada arena pengujian. Kemudian robot diletakkan didepan QR Code tersebut dengan beberapa variabel jarak. Pengujian ini dilakukan sebanyak tujuh kali.

2. Pengujian waktu navigasi robot dari suatu lokasi ke lokasi lain. Pada pengujian ini dilakukan perbandingan waktu navigasi yang dilakukan dengan teleoperasi oleh penulis dan waktu navigasi secara otonom. Pengujian waktu navigasi teleoperasi dan otonom masing-masing dilakukan sebanyak lima kali. Pada setiap pengujian dilakukan navigasi dari Home ke Stasiun 1, Stasiun 1 ke Stasiun 2, Stasiun 2 ke Stasiun 3, dan Stasiun 3 ke Stasiun 1.

\section{HASIL DAN PEMBAHASAN}

Berikut merupakan hasil dari dua tipe pengujian yang telah dilakukan penulis.

\subsection{Pengujian Pendeteksian QR Code}

Tabel 1 merupakan hasil pengujian pendeteksian QR Code. Berdasarkan hasil pengujian pada tabel 1 dapat dilihat bahwa robot tidak dapat mendeteksi QR Code pada jarak $40 \mathrm{~cm}$ keatas dan $5 \mathrm{~cm}$ kebawah. Jika robot berada pada jarak $20 \mathrm{~cm}$ dan $10 \mathrm{~cm}$ dari QR Code robot dapat mendeteksi QR Code berukuran 5 x 5 $\mathrm{cm}$. Sedangkan penelitian sebelumnya yang dilakukan oleh Zhang, QR Code yang digunakan berukuran 12 x $12 \mathrm{~cm}$. Dimana penulis berhasil membuat perangkat lunak untuk membaca $Q R$ Code dengan ukuran yang lebih kecil lima kali dari penelitian sebelumnya.

Tabel 1. Hasil Pengujian Pendeteksian QR Code

\begin{tabular}{cc}
\hline Jarak & Hasil \\
\hline $100 \mathrm{~cm}$ & Tidak terdeteksi \\
\hline $80 \mathrm{~cm}$ & Tidak terdeteksi \\
\hline $60 \mathrm{~cm}$ & Tidak terdeteksi \\
\hline $40 \mathrm{~cm}$ & Tidak terdeteksi \\
\hline $20 \mathrm{~cm}$ & Terdeteksi \\
\hline $10 \mathrm{~cm}$ & Terdeteksi \\
\hline $5 \mathrm{~cm}$ & Tidak terdeteksi \\
\hline
\end{tabular}

\subsection{Pengujian Waktu Navigasi}

Tabel 2 merupakan hasil pengujian waktu navigasi yang dilakukan dengan teleoperasi oleh penulis. Pada tabel 2 dapat dilihat waktu navigasi secara teleoperasi dari Home ke Stasiun 1 membutuhkan waktu rata-rata 21,50 detik. Navigasi secara teleoperasi dari Stasiun 1 ke Stasiun 2 membutuhkan waktu ratarata 36,52 detik. Navigasi secara teleoperasi dari Stasiun 2 ke Stasiun 3 membutuhkan waktu rata-rata 28,48 detik. Kemudian navigasi secara teleoperasi dari Stasiun 3 ke Stasiun 1 membutuhkan waktu rata-rata 18,07 detik. Tabel 3 merupakan hasil pengujian waktu navigasi yang dilakukan secara otonom. 
Tabel 2. Hasil Pengujian Waktu Navigasi Teleoperasi

\begin{tabular}{lcccccc}
\hline \multicolumn{1}{c}{ Navigasi } & I (s) & II (s) & III (s) & IV (s) & V (s) & Mean (s) \\
\hline Home - Stasiun 1 & 21,07 & 21,93 & 21,54 & 19,58 & 23,40 & 21,50 \\
\hline Stasiun 1 - Stasiun 2 & 36,97 & 39,50 & 36,21 & 36,29 & 33,63 & 36,52 \\
\hline Stasiun 2 - Stasiun 3 & 30,46 & 29,34 & 26,22 & 26,55 & 29,82 & 28,48 \\
\hline Stasiun 3 - Stasiun 1 & 18,34 & 19,68 & 17,25 & 16,79 & 18,29 & 18,07 \\
\hline
\end{tabular}

Tabel 3. Hasil Pengujian Waktu Navigasi Otonom

\begin{tabular}{lcccccc}
\hline \multicolumn{1}{c}{ Navigasi } & I (s) & II (s) & III (s) & IV (s) & V (s) & Mean (s) \\
\hline Home - Stasiun 1 & 35,16 & 34,13 & 30,52 & 28,66 & 28,93 & 31,48 \\
\hline Stasiun 1 - Stasiun 2 & 47,79 & 48,25 & 44,53 & 44,68 & 50,51 & 47,15 \\
\hline Stasiun 2 - Stasiun 3 & 40,21 & 48,77 & 38,94 & 44,72 & 39,69 & 42,45 \\
\hline Stasiun 3 - Stasiun 1 & 13,55 & 15,37 & 12,41 & 15,45 & 11,74 & 13,71 \\
\hline
\end{tabular}

Pada tabel 3 diatas dapat dilihat waktu navigasi secara otonom dari Home ke Stasiun 1 membutuhkan waktu rata-rata 31,48 detik. Navigasi secara otonom dari Stasiun 1 ke Stasiun 2 membutuhkan waktu rata-rata 47,15 detik. Navigasi secara teleoperasi dari Stasiun 2 ke Stasiun 3 membutuhkan waktu ratarata 42,45 detik. Kemudian navigasi secara teleoperasi dari Stasiun 3 ke Stasiun 1 membutuhkan waktu rata-rata 13,71 detik. Jika data rata-rata dari kedua pengujian diatas disatukan dalam satu tabel 4 .

Tabel 4. Hasil Pengujian Waktu Rata-Rata Navigasi

\begin{tabular}{lcc}
\hline \multicolumn{1}{c}{ Navigasi } & Teleoperasi (s) & Otonom (s) \\
\hline Home - Stasiun 1 & 21,50 & 31,48 \\
\hline Stasiun 1 - Stasiun 2 & 36,52 & 47,15 \\
\hline Stasiun 2 - Stasiun 3 & 28,48 & 42,45 \\
\hline Stasiun 3 - Stasiun 1 & 18,07 & 13,71 \\
\hline
\end{tabular}

Berdasarkan tabel 4 diatas, waktu rata-rata navigasi secara teleoperasi memiliki waktu yang lebih rendah kecuali saat navigasi dari Stasiun 3 ke Stasiun 1. Perbedaan waktu rata-rata navigasi antara teleoperasi dan otonom ini umum terjadi. Hal ini disebabkan oleh faktor pembacaan sensor dan keadaan arena. Karena terdapat banyak sekali pilihan jalur yang dapat dilalui oleh robot, sehingga pada saat pengujian robot melalui jalur yang berbeda-beda untuk mencapai ke tujuan. Pemilihan jalur ini tergantung pada beberapa faktor pembacaan sensor dan algoritma yang digunakan.

\section{KESIMPULAN}

Penelitian ini telah berhasil membuat perangkat lunak untuk kontrol dan pendeteksian QR Code pada robot mobil yang akan digunakan pada pabrik garmen. Perangkat lunak yang dihasilkan berupa lima buah program bahasa python yang saling terkait satu dengan yang lain. Dengan adanya perangkat lunak ini robot telah berhasil melakukan navigasi secara otonom dan mendeteksi QR Code.

\section{DAFTAR PUSTAKA}

[1] J. Immanuel, "Implementasi Evolutionary Neural Network Pada Simulasi Autonomous Mobile Robot Navigation," Universitas Multimedia Nusantara, 2019.

170 Juan Steven
[2] L. C. Básaca-Preciado et al., "Optical 3D laser measurement system for navigation of autonomous mobile robot," Opt. Lasers Eng., vol. 54, pp. 159-169, 2014, doi: 10.1016/i.optlaseng.2013.08.005.

[3] F. Umam, "Pengembangan Sistem Kendali Pergerakan Autonomous Mobile Robot Untuk Mendapatkan Jalur Bebas," J. Ilm. Mikrotek, vol. 1, no. 1, pp. 35-42, 2013.

[4] A. H. Pratomo, M. S. Zakaria, and S. Prabuwono, "Model Dan Teknik Kalibrasi Citra Untuk Sistem Autonomous Robot," vol. 2009, no. semnasIF, pp. 94 100, 2009.

[5] M. Kurniawan and R. N. Pramesti, "Analisis Penanganan Bahan (Material Handling) Produk Teh Di Pt Perkebunan Nusantara Xii Kebun Teh Wonosari Dengan Menggunakan Material Handling General Analysis Procedure," Tekmapro J. Ind. Eng. Manag., vol. 14 , no. 1 , pp. 52-58, 2019, doi: 10.33005/tekmapro.v14i1.29.

[6] E. Gambao, M. Hernando, and D. Surdilovic, "A new generation of collaborative robots for material handling," 2012 Proc. 29th Int. Symp. Autom. Robot. Constr. ISARC 2012, no. June, 2012, doi: 10.22260/isarc2012/0076.

[7] H. Gultekin, S. Gürel, and R. Taspinar, "Bicriteria scheduling of a material handling robot in an m-machine cell to minimize the energy consumption of the robot and the cycle time," Robot. Comput. Integr. Manuf., vol. 72, no. June, p. 102207, 2021, doi: 10.1016/j.rcim.2021.102207.

[8] S. Maeda, N. Tsujiuchi, T. Koizumi, M. Sugiura, and H. Kojima, "Development and control of a pneumatic robot arm for industrial fields," Int. J. Adv. Robot. Syst., vol. 9, pp. 1-7, 2012, doi: $10.5772 / 50538$.

[9] S. Tiwari, "An Introduction To QR Code Technology," in 2016 International Conference on Information Technology, 2016, no. December 2016, pp. 39-44, doi: 10.1109/ICIT.2016.38.

[10] A. Jecinth and S. Singh, "QR Code Analysis," Int. J. Adv. Res. Comput. Sci. Softw. Eng., vol. 6, no. 5, p. 2277, 2016, [Online]. Available: www.ijarcsse.com.

[11] S. Okazaki, H. Li, and M. Hirose, "Benchmarking the use of QR code in mobile promotion: Three studies in Japan," J. Advert. Res., vol. 52, no. 1, pp. 102-117, 2012, doi: 10.2501/JAR-52-1-102-117.

[12] Y. H. Lin, Y. P. Chang, and J. L. Wu, "Appearancebased QR code beautifier," IEEE Trans. Multimed., vol. 15 , no. 8, pp. 2198-2207, 2013, doi: 10.1109/TMM.2013.2271745.

[13] T. S. Teuta Cata, Payal S. Patel, "QR Code: A New Opportunity for Effective Mobile Marketing," J. Mob. 
Technol. Knowl. Soc., vol. 2013, 2013, doi: $10.5171 / 2013$.

[14] A. Ravankar, A. A. Ravankar, Y. Kobayashi, Y. Hoshino, and C. C. Peng, "Path smoothing techniques in robot navigation: State-of-the-art, current and future challenges," Sensors (Switzerland), vol. 18, no. 9, pp. 130, 2018, doi: 10.3390/s18093170.

[15] H. Zhang, C. Zhang, W. Yang, and C. Y. Chen, "Localization and navigation using QR code for mobile robot in indoor environment," 2015 IEEE Int. Conf. Robot. Biomimetics, IEEE-ROBIO 2015, no. March, pp. 2501-2506, 2015, doi: 10.1109/ROBIO.2015.7419715.

\section{BIODATA PENULIS}

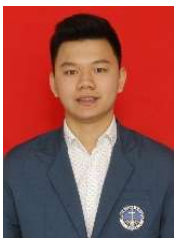

Penulis Pertama

Penulis bernama lengkap Juan Steven. Penulis merupakan mahasiswa S1 di Program Studi Teknik Elektro Universitas Kristen Petra Surabaya Angkatan 2018. Penulis mengambil konsentrasi studi di bidang elektronika.

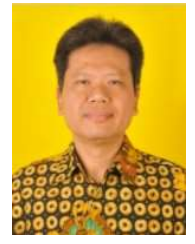

Penulis Kedua

Penulis bernama lengkap Ir. Resmana Lim, M.Eng. Saat ini penulis memiliki jabatan sebagai dosen tetap di Program Studi Teknik Elektro Universitas Kristen Petra. 